\title{
Profil Aktivitas Ekonomi Masyarakat Perikanan sekitar Waduk di Jawa Barat
}

\author{
[Profile of Economic Activity of Fisheries around the Reservoir in West Java] \\ M. Harja Supena ${ }^{\bowtie}$, Sobariah \\ Sekolah Tinggi Perikanan, Jurusan Penyuluhan Perikanan \\ Jalan Cikaret Nomor 1 Bogor 16001, Jawa Barat \\ Diterima: 05 Agustus 2017; Disetujui: 25 Agustus 2017
}

\begin{abstract}
Abstrak
Penelitian ini bertujuan untuk mengetahui profil kegiatan ekonomi masyarakat di sekitar waduk. Metode yang digunakan adalah Metode Deskriptif dengan pendekatan Kualitatif dan Kuantitatif. Pengambilan sampel menggunakan Tehnik Purposive Sampling, yaitu sampel dilakukan terhadap pelaku utama perikanan yang ada di 5 waduk (Waduk Jatiluhur, Waduk Cirata,Waduk Saguling,Waduk Jatigede, dan Waduk Darma). Tehnik pengumpulan data menggunakan wawancara dengan menggunakan instrumen berupa kuesioner yang berisi open dan close question. Dalam pengolahan data dilakukan penetapan nilai (skor) terhadap setiap pertanyaan yang berada dalam setiap sub sistem usaha. Hasil penelitian terhadap 5 waduk yang ditinjau dari 5 sub sistem usaha (sarana produksi, produksi, pasca produksi, pemasaran, dan layanan pendukung) diperoleh nilai (skor) sebagai berikut: Waduk Jatiluhur (10,96), Waduk Cirata $(9,24)$, Waduk Saguling $(10,86)$, Waduk Jatigede $(9,32)$, dan Waduk Darma $(8,92)$. Dari hasil penilaian tersebut, maka diperoleh gambaran tentang profil aktivitas ekonomi masyarakat di sekitar waduk. Semoga penelitian ini dapat dijadikan sebagai bahan referensi untuk menambah kepustakaan dan pengembangan pengetahuan tentang profil aktivitas ekonomi masyarakat di sekitar waduk,
\end{abstract}

Kata kunci: ekonomi masyarakat perikanan, lima subsistem usaha

\begin{abstract}
This study aims to determine the profile of economic activities of people around the reservoir. The method used is Descriptive Method with Qualitative and Quantitative approach. Sampling is using Purposive Sampling Technique, that is samples conducted on the main perpetrators of fisheries in 5 reservoirs (Jatiluhur Reservoir, Cirata Reservoir, Saguling Reservoir, Jatigede Reservoir, and Darma Reservoir). Technique of data collection using interview with using instrument in the form of questionnaires that contain open and close question. In the data processing is done determination of value (score) to every question that is in every sub system business. The results of research on 5 reservoirs observed from 5 sub business systems (production facilities, production, post production, marketing, and support services) obtained value (score) as follows: Jatiluhur Reservoir (10,96), Cirata Reservoir (9,24) , Saguling Reservoir (10.86), Jatigede Reservoir $(9,32)$, and Darma Reservoir $(8,92)$. From the results of these assessments, then obtained a picture about the profile of economic activities of communities around the reservoir. Hopefully this research can be used as reference material to add library and knowledge development about economic activity profile of society around reservoir.
\end{abstract}

Keywords: fishery community economy, five business subsystems

$\triangle$ Penulis korespondensi

Alamat surel: harja_s@yahoo.co.id 


\section{PENDAHULUAN}

\begin{abstract}
Waduk adalah danau buatan, yang diwujudkan dengan cara membendung sungai untuk menyimpan air dalam jumlah besar (Andrijanto \& Pamungkas, 2011). Jawa Barat merupakan salah satu provinsi yang memiliki banyak waduk lima diantaranya adalah Waduk Cirata dan
\end{abstract} Jatiluhur di Kabupaten Purwakarta, Waduk Saguling di Kabupaten Bandung Barat, Waduk Jatigede di Kabupaten Sumedang, dan Waduk Darma di Kabupaten Kuningan Jawa Barat. Waduk merupakan salah satu wadah atau tempat yang digunakan sebagai salah satu peluang usaha bagi para penduduk sekitar baik sebagai nelayan maupun pembudidaya ikan dengan menggunakan Sistem Jaring Terapung, Salah satu contohnya adalah Keramba Jaring Apung (KJA).

Dari lima waduk di atas, Cirata dan Jatiluhur merupakan waduk yang lebih dahulu dibangun lalu disusul dengan Saguling, Jatigede, dan Darma. Cirata merupakan waduk dengan bangunan tertinggi sedangkan Jatiluhur merupakan waduk terluas. Dari sisi tingkat penyuburan perairan/eutrofikasi, Saguling dan Cirata termasuk kategori mesotrophic (kesuburan sedang) dan dua waduk yang masih terbilang baru, yaitu Jatigede dan Darma termasuk kategori oligotrophic (miskin unsur hara). Berdasarkan karakteristik waduk tersebut di atas, maka sudah barang tentu aktivitas ekonomi masyarakat perikanannyapun menjadi lebih variatif. Oleh karena itu profil aktivitas masyarakat perikanan di lima waduk Jawa Barat menjadi penting untuk dikaji dan dianalisa dari sisi aspek ekonomi sistem bisnis perikanan yang mencakup lima subsistem, yaitu: (a) subsistem sarana produksi; (b) subsistem produksi;

(c) subsistem pasca produksi; (d) subsistem pemasaran; dan (e) subsistem Layanan Pendukung.

Tujuan dari penelitian ini adalah untuk mengetahui profil kegiatan ekonomi masyarakat pada lima waduk di Jawa Barat yaitu: Waduk Cirata, Waduk Jatiluhur, Waduk Saguling, Waduk Jatigede, dan Waduk Darma.

\section{BAHAN DAN METODE}

Penelitian dilakukan di lima lokasi yaitu: (1) Waduk Cirata di Kecamatan Manis Kabuparten Purwakarta, (2) Waduk Jatiluhur di Kecamatan Sukatani Kabuparten 
Purwakarta, (3) Waduk Saguling di Kecamatan Cililin Kabuparten Bandung Barat, (4) Waduk Jatigede di Kecataman Darmaraja Kabuoaten Sumedang, dan (5) Waduk Darma di Kecamatan Darma Kabupaten Kuningan. Penelitian dilakukan dari Bulan April sampai dengan Agustus 2017.

Pengambilan sampel dilakukan dengan menggunakan Teknik Purposive Sampling, yaitu sampel dilakukan terhadap pelaku utama perikanan yang ada di lima waduk. Pengumpulan data dilakukan melalui wawancara dengan menggunakan instrument berupa kuesionar yang berisi open dan close question. Pengolahan data dilakukan menggunakan Metode Deskriptif dengan Pendekatan Kualitatif dan Kuantitatif. Dalam pengolahan data dilakukan penetapan nilai (skor) terhadap setiap pertanyaan yang berada dalam setiap Sub Sistem Aspek Ekonomi atau sistem bisnis perikanan. Berdasarkan skoring tersebut, maka dapat diperoleh profile aktivitas ekonomi masyarakat perikanan sekitar waduk di Jawa Barat.

\section{HASIL DAN PEMBAHASAN}

Ketinggian suatu tempat dapat berpengaruh terhadap perubahan suhu udara. Berdasarkan letak ketinggian dari permukaan laut, Kabupaten Purwakarta, Bandung Barat, Sumedang, dan Kuningan masing-masing berada pada ketinggian $223 \mathrm{~m}, 110 \mathrm{~m}, 1.000 \mathrm{~m}$, dan $700 \mathrm{~m}$ di atas permukaan laut (dpl). Akibat adanya perbedaan suhu tersebut, maka jenis atau species ikan yang ada dan hidup di waduk di setiap lokasi tersebutpun kemungkinan dapat berbeda pula. Baik ikan asli waduk maupun ikan-ikan introduksi yang sengaja ditebarkan ke perairan waduk atau yang secara tidak sengaja masuk ke dalam perairan waduk.

Selain faktor ketinggian, faktor kondisi waduk terutama yang terkait dengan tingkat pencemaran (pollution) juga dapat mempengaruhi jumlah produksi dan jenis species ikan. Sebagaimana kita ketahui bahwa dari lima waduk tersebut di atas, pembangunan dan pendiriannya berbeda-beda. Adapun tahun pendirian atau pembangunan waduk dimaksud adalah sebagai berikut: Waduk Jatiluhur 1957, Waduk Cirata 1983, Waduk

Saguling 1985, Waduk Jati Gede 2005, dan Waduk Darma 1965 (Anonimus $^{-1}$, 2017). Dengan 
demikian setiap waduk mempunyai karakteristik yang berbeda- beda terutama dari sisi tingkat beban masukan unsur haranya. Sebagai contoh Waduk Saguling dan Cirata termasuk pada katagori

Tabel 1. Profil dan Kondisi masing-masing waduk areal penelitan

\section{No. Nama Waduk dan Profil/Kondisi masing-masing Waduk}

1. Waduk Jatiluhur (Anonimus ${ }^{-1)}$, 2017)

- Berlokasi di Kabupaten Purwakarta,

- Kabupaten Purwakarta memiliki 17 kecamatan (Kecamatan: Babakancikao, Bojong, Bungur Sari, Campaka, Cibatu, Darangdang, Jatiluhur, Kiara Pedes, Maniis, Pasawahan, Plered, Pedel Soken, Purwakarta, Sukasari, Sukatani, Tegal Waru, dan Wanayasa)

- Dibangun pada tahun 1957 dan merupakan waduk tertua dan terbesar di Indonesia

- Membendung aliran Sungai Citarum di Kecamatan Jatiluhur

- Volume tampungan 2,44 milyar m3 dengan luas genangan 8.300 ha

- Salah satu fungsinya sebagai objek perikanan air tawar

2. Waduk Cirata (Anonimus ${ }^{2}$, 2017)

- Berlokasi di Kabupaten Purwakarta (tepatnya di Desa Cadas Sari, Kecamatan Tegal Waru, Plered)

- $\quad$ Berada di 3 Kabupaten (Purwakarta, Cianjur, Bandung Barat), Area Cianjur lebih luas

- Dibangun pada tahun 1983

- Sumber air dari Sungai Citarum Jawa Barat

- Volume tampungan 2.165 juta m3 dengan luas genangan 6.200 ha

- $\quad$ Luas danau 43.777 ha

- Luas Waduk Cirata, dari ujung selatan Kecamatan Cipeundeuy Kabupaten Bandung Barat, dan terbendung di Desa Ciroyom, Kecamatan Cipeundeuy Kabupaten Bandung Barat, yang berbatasan langsung dengan Kecamatan Manis Kabupaten Purwakarta

- Berfungsi sebagai PLTA, objek perikanan darat, dan destinasi liburan (Anonimus3) 2017)

- Genangan air berasal dari waduk saguling yang letaknya lebih tinggi, lalu dari

3. Waduk Saguling ((Anonimus ${ }^{2)}$, 2017)

- Berlokasi di Kabupaten Bandung Barat

- Kabupaten Bandung Barat memiliki 16 kecamatan (Kecamatan: Batujajar, Cipongkor, Rongga, Cikalongwetan, Cisarua, Sindangkerta, Cihampleas, Gununghalu, Lembang, Cililin, Ngamprah, Saguling, Cipatat, Padalarang, Cipeundeuy, dan Parongpong)

- Dibangun pada tahun 1985

- Sumber air dari Sungai Citarum Jawa Barat

- Volume tampungan 875 juta m3 dengan luas genangan 2.271,7 m2

- Waduk Saguling dari empat daerah yaitu: Kota Bandung, Kota Cimahi, Kabupaten Bandung dan Kabupaten Bandung Barat.

- Berfungsi sebagai PLTA lalu ditata ulang sebagai bendungan multiguna, termasuk untuk kegunaan perikanan, agri-akuakultur, pariwisata, dan lain-lain. Sekarang, waduk ini juga digunakan untuk kebutuhan lokal seperti mandi, dan mencuci.

- Pada sistem waduk kaskade Citarum,Waduk Saguling berada di daerah paling 
4. Waduk Jatigede ((Anonimus ${ }^{2)}$, 2017)

- Berlokasi di Kabupaten Sumedang

- Kabupaten memiliki 26 kecamatan (Kecamatan: Buah Dua, Cibugel, Cimalaka, Cimanggung, Cisarua, Cisitu, Conggeang, Darmaraja, Ganeas, Jatigede, Jaatinangor, Jatinunggal, Pamulihan, Paseh, Ranca Kalong, Situraja, Sukasari, Sumedang Selatan, Sumedang Utara, Surian, Tanjungkerta, Tanjungmedar, Tanjungsari, Tomo, Ujungjaya, dan Wado)

- Dibangun pada tahun 2005

- Sumber air dari Sungai Cimanuk Jawa Barat

- Volume tampungan 980 juta m3 dengan luas genangan 16,58 ha

- Berfungsi sebagai irigasi dan Pembangkit Tenaga Listrik lalu berkembang menjadi sarana budidaya perikanan air tawar, sarana olahraga air, sarana rekreasi, dan lain sebagainya

5 Waduk Darma ((Anonimus ${ }^{2)}$, 2017)

- Berlokasi di Kabupaten Kuningan, tepatnya di Kec. Darma

- Kabupaten Sumedang memiliki 26 kecamatan (Kecamatan: Buah Dua, Cibugel, Cimalaka, Cimanggung, Cisarua, Cisitu, Conggeang, Darmaraja, Ganeas, Jatigede, Jaatinangor, Jatinunggal, Pamulihan, Paseh, Ranca Kalong, Situraja, Sukasari, Sumedang Selatan, Sumedang Utara, Surian, Tanjungkerta, Tanjungmedar, Tanjungsari, Tomo, Ujungjaya, dan Wado)

- Dibangun pada tahun 1965

- Sumber air dari Sungai Cimanuk Jawa Barat

- Volume tampungan 36,9 juta m3 dengan luas genangan 39,44 ha

- Berfungsi sebagai obyek wisata, penyuplai air PDAM dan Pertanian (Kuningan dan Cirebon) dan lain sebagainya 
Tabel 2. Rekapitulasi penilaian/skor lima sub sistem bisnis perikanan pada lima waduk

\begin{tabular}{|c|c|c|c|c|c|c|c|c|}
\hline No & Sub-sistem Bisnis & Jatiluhur & Cirata & Saguling & Jatigede & Darma & Jumlah & Rataan \\
\hline 1. & Sarana Produksi & 1.89 & 1.44 & 2.32 & 1.89 & 1.82 & 9.36 & 1.87 \\
\hline 2. & Produksi & 1.71 & 1.72 & 1.47 & 1.53 & 1.25 & 7.68 & 1.54 \\
\hline 3. & Pasca Produksi & 2.18 & 1.70 & 2.39 & 1.63 & 1.50 & 9.40 & 1.88 \\
\hline 4. & Pemasaran & 3.21 & 2.34 & 2.69 & 2.43 & 2.25 & 12.92 & 2.58 \\
\hline 5. & Layanan Pendukung & 1.97 & 2.04 & 1.99 & 1.84 & 2.10 & 9.94 & 1.99 \\
\hline & Jumlah & 10.96 & 9.24 & 10.86 & 9.32 & 8.92 & 49.30 & 9.86 \\
\hline
\end{tabular}

eutrophic (sangat subur/kaya unsur

hara). Waduk Jatiluhur termasuk pada

kategori mesotrophic (tingkat kesuburan

sedang), sedangkan Jatigede dan Darma

termasuk kategori oligotrophic (miskin

unsur hara). Khusus pada Waduk

Jatiluhur, Sukimim, 1999) menyatakan

bahwa sejak tahun 1996, arah arus

permukaan cenderung bergerak dari

zona mengalir yang memiliki ciri

berarus deras dengan ketersediaan unsur

hara tinggi (beban masukan dari arah

hulu/inlet): menuju ke zona lakustrin

yang memiliki ciri proses sedimentasi

lambat. hal ini akan menimbulkan

peningkatan pencemaran pada zona

lakustrin. Salah satu upaya mencegah

tinggi unsur hara masuk kedalam badan

perairan waduk, menurut Tjokrokusumo

(2000) adalah dengan melakukan

diversifikasi tanaman pinggiran waduk

yang mampu memperlambat erosi

tepian sungai. Profil setiap waduk

dari berbagai sumber, dapat dilihat pada Tabel 1 .

Dari profil masing-masing waduk di atas dan hasil wawancara dengan menggunakan instrumen/alat berupa kuesioner kepada sejumlah 30 orang responden pelaku utama perikanan terhadap lima aspek ekonomi dari sistem bisnis perikanan, yaitu: Sub Sistem Sarana Produksi, Sub Sistem Produksi, Sub Sistem Pasca Produksi, Sub Sistem Pemasaran, dan Sub Sistem Layanan Pendukung, dimana masing- masing sub sitem mempunyai beberapa kriteria, maka setelah dilakukan penilaian dengan menggunakan skor 1 sampai 3 (skor $1=$ kurang, skor 2= cukup, skor 3= baik) diperoleh hasil seperti pada Tabel 2

Berdasarkan Tabel 2 di atas, nilai atau skor yang diperoleh pada setiap waduk berasal dari lima aspek ekonomi yang terdiri dari lima sub sistem (Sub 
Sistem Sarana Produksi, Sub Sistem

Produksi, Sub Sistem Pasca Produksi,

Sub Sistem Pemasaran, Sub Sistem

Layanan Pendukung), dimana masing- masing sub sistem mempunyai sejumlah kriteria yang berbeda-beda yaitu sebagai berikut: a). Sub Sistem Sarana Produksi mempunyai tiga criteria utama penilaian

Tabel 2. Rekapitulasi penilaian (skor) lima subsistem sesuai dengan criteria masing-masing

\begin{tabular}{|c|c|c|c|c|c|}
\hline $\begin{array}{l}\text { Sub-sistem bisnis } \\
\text { dan kriteria }\end{array}$ & $\begin{array}{l}\text { Waduk } \\
\text { Jatiluhur }\end{array}$ & $\begin{array}{l}\text { Waduk } \\
\text { Cirata }\end{array}$ & $\begin{array}{c}\text { Waduk } \\
\text { Saguling }\end{array}$ & $\begin{array}{c}\text { Waduk } \\
\text { Jatigede }\end{array}$ & $\begin{array}{l}\text { Waduk } \\
\text { Darma }\end{array}$ \\
\hline \multicolumn{6}{|l|}{ Sarana Produksi } \\
\hline Status kepemilikan & 3.55 & 2.42 & 2.52 & 2.94 & 2.55 \\
\hline Jumlah sarana & 0.97 & 1.00 & 2.45 & 1.29 & 1.22 \\
\hline Ketersediaan sarana & 1.16 & 0.91 & 2.00 & 1.43 & 1.75 \\
\hline Jumlah & 5.68 & 4.33 & 6.97 & 5.66 & 5.47 \\
\hline Rataan & 1.89 & 1.44 & 2.32 & 1.89 & 1.82 \\
\hline \multicolumn{6}{|l|}{ Produksi } \\
\hline Skala produksi & 1.29 & 1.29 & 1.00 & 1.17 & 1.00 \\
\hline Tehnik produksi & 1.40 & 1.50 & 1.97 & 1.06 & 0.35 \\
\hline Jenis hasil produksi & 1.32 & 1.82 & 1.00 & 1.67 & 1.00 \\
\hline Jumlah tenaga kerja & 1.67 & 1.42 & 1.00 & 1.00 & 1.00 \\
\hline Orientasi Usaha pokok & 2.90 & 2.55 & 2.37 & 2.75 & 2.90 \\
\hline Jumlah & 8.57 & 8.58 & 7.34 & 7.64 & 6.25 \\
\hline Rataan & 1.71 & 1.72 & 1.47 & 1.53 & 1.25 \\
\hline \multicolumn{6}{|l|}{ Pasca Produksi } \\
\hline Tehnik pengemasan & 2.26 & 1.44 & 2.18 & 1.42 & 1.50 \\
\hline Bahan pengemasan & 2.50 & 2.50 & 3.00 & 2.33 & 2.00 \\
\hline Teknik pasca panen & 1.79 & 1.16 & 2.00 & 1.13 & 1.00 \\
\hline Jumlah & 6.55 & 5.10 & 7.18 & 4.88 & 4.50 \\
\hline Rataan & 2.18 & 1.70 & 2.39 & 1.63 & 1.50 \\
\hline \multicolumn{6}{|l|}{ Pemasaran } \\
\hline Strategi pemasaran & 2.64 & 2.61 & 2.61 & 2.69 & 2.50 \\
\hline Sistem pembayaran & 4.38 & 2.69 & 2.97 & 2.85 & 2.75 \\
\hline Promosi & 2.20 & 1.67 & 3.00 & 1.29 & 1.00 \\
\hline \multicolumn{6}{|l|}{ Fungsi Pemasaran } \\
\hline Fungsi transportasi & 3.66 & 2.25 & 2.18 & 2.63 & 2.00 \\
\hline Fungsi penyimpanan & 3.75 & 2.22 & 2.39 & 2.47 & 2.75 \\
\hline Fungsi peretukaran & 2.65 & 2.60 & 3.00 & 2.61 & 2.50 \\
\hline Jumlah & 19.27 & 14.03 & 16.15 & 14.55 & 13.50 \\
\hline Rataan & 3.21 & 2.34 & 2.69 & 2.43 & 2.25 \\
\hline \multicolumn{6}{|l|}{ Layanan Pendukung } \\
\hline Sarana tranportasi & 2.00 & 2.12 & 2.03 & 2.18 & 2.50 \\
\hline Fasilitas komunikasi & 2.10 & 2.22 & 2.27 & 2.22 & 2.00 \\
\hline \multicolumn{6}{|l|}{ Lembaga keuangan } \\
\hline Keberadaan dan peran & 2.21 & 2.35 & 2.64 & 1.53 & 2.50 \\
\hline Tingkat pemanfaatan & 2.15 & 2.17 & 2.03 & 2.00 & 2.50 \\
\hline Status lembaga usaha & 1.38 & 1.36 & 0.97 & 1.28 & 1.00 \\
\hline Jumlah & 9.83 & 10.22 & 9.94 & 9.21 & 10.50 \\
\hline Rataan & 1.97 & 2.04 & 1.99 & 1.84 & 2.10 \\
\hline
\end{tabular}


(status kepemilikan, jumlah sarana, dan ketersediaan sarana), b) Sub Sistem Produksi mempunyai lima kriteria penilaian (skala produksi, tehnik produksi, jenis hasil produksi, jumlah serapan tenaga kerja, dan orientasi usaha pokok), c) Sub Sistem Pasca Produksi mempunyai tiga kriteria penilaian (tehnik pengemasan, kemudian bahan pengemasan, dan tehnik pasca panen), d). Sub Sistem Pemasaran mempunyai empat kriteria penilaian (strategi pemasaran, juga sistem pembayaran,

promosi, dan fungsi pemasaran= tiga kriteria), e). Sub Sistem Layanan Pendukung mempunyai empat kriteria penilaian (sarana transportasi, fasilitas komunikasi,lembaga keuangan = dua kriteria,dan status lembaga usaha). Dengan demikian, nilai (skor) yang diperoleh pada masing-masing waduk sesuai dengan jumlah kriteria di atas dapat dilihat pada Tabel 2.

Jika mengacu pada Tabel 2. diatas, maka secara ranking Waduk Jatiluhur menempati urutan pertama dengan total skor $(10,95)$. Urutan kedua Waduk Saguling $(10,86)$, urutan ketiga Waduk Cirata 9,24), urutan keempat Waduk Jatigede $(9,32)$, dan urutan kelima Waduk Darma $(8,92)$. Urutan ranking tersebut dapat mengindikasikan bahwa aktivitas tingkat kegiatan perekonomian masyarakat perikanan di seputar Waduk Jatiluhur juga lebih tinggi dibandingkan dengan areal Waduk Saguling. Waduk Saguling yang tertinggi aktivitasnya dibandingkan dengan Waduk Cirata, demikian seterusnya.

Khusus untuk Waduk Jatiluhur, terlihat kegiatan ekonomi masyarakat lebih banyak bergantung kepada usaha perikanan budidaya KJA yang dikembangkan dengan sistem polikultur. Menurut penelitian Amidarhana (2001) R/C ratio usaha budidaya ikan KJA dengan sistem polikultur tercatat sebesar 1,70, dibanding dengan sistem monokultur yang tercatat $\mathrm{R} / \mathrm{C}$ ratio sebesar 1,35 .

Dilihat dari total skor, Waduk Jatiluhur lebih tinggi dibandingkan dengan empat waduk lainnya. Hal ini disebabkan karena Waduk Jatiluhur merupakan waduk yang lebih dahulu dibangun dibandingkan dengan empat waduk lainnya. Hal ini terbukti seperti yang terlihat pada Tabel 3, dimana dari lima sub sistem usaha tersebut empat diantaranya memiliki skor lebih tinggi dibanding empat 
waduk lainnya. Hanya pada Sub Sistem Layanan Pendukung saja yang nilainya berada di bawah Waduk Cirata. Dimana Waduk Cirata memperoleh skor 2,04 sedangkan Waduk Jatiluhur memperoleh skor rata- rata 1,97. Kodisi ini juga ditengarai karena adanya perbedaan persepsi antar pemangku kepentingan, menurut Hidayat dkk (2016) tidak jelasnya aturan menjalankan usaha dari persepsi pemerintah dan pelaku usaha menimbulkan fluktuasi pada kondisi usaha perikanan tangkap di Waduk Cirata yang tercatat pada kurun tahun 2015 sebanyak 3.511,38 ton; dan tahun 2015, sebanyak 3,583,41 ton. Pilihan jenis ikan yang dibudidayakan juga berfluktuasi, karena perhitungan ekonomi. Nugroho (2011) mencatat jaminan harga terbaik untuk jenis ikan nila selain ikan mas pada KJA adalah dengan harga jual diatas $\mathrm{Rp}$ 11.000 per- kg, yaitu harga jual pada tahun 2011.

Lebih lanjut, selisih skor tersebut terlihat pada kriteria Sarana Transportasi, Fasilitas Komunikasi, dan Lembaga Keuangan. di Waduk Cirata. Disitu terlihat Waduk Jatiluhur memperoleh skor $(8,46)$, sedangkan
Waduk Cirata memperoleh skor $(8,86)$. Lebih tingginya skor pada kriteria Sarana Transportasi, Fasilitas Komunikasi, dan Lembaga Keuangan di Waduk Cirata tersebut dapat disebabkan karena Waduk Cirata lebih banyak dijadikan sebagai destinasi liburan lantaran lokasinya yang lebih strategis dan mudah dijangkau, sehingga jumlah pengunjungnyapun lebih banyak. Disamping itu dari sisi panoramanya,Waduk Cirata lebih indah dibandingkan dengan Waduk jatiluhur terutama saat matahari

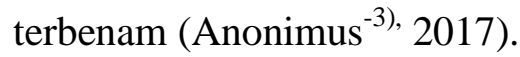

Jika mengacu pada Tabel 2 diatas, maka secara ranking Waduk Jatiluhur menempati urutan pertama dengan total skor (10,96). Urutan kedua Waduk Saguling $(10,86)$, urutan ketiga Waduk Cirata 9,24), urutan keempat Waduk Jatigede (9,32), dan urutan kelima Waduk Darma $(8,92)$. Urutan ranking tersebut mengindikasikan bahwa aktivitas kegiatan perekonomian masyarakat perikanan di Waduk Jatiluhur lebih tinggi dibandingkan dengan Waduk Saguling. Waduk Saguling lebih tinggi aktivitasnya dibandingkan dengan Waduk Cirata, demikian seterusnya. Khusus untuk 
Waduk Jatiluhur, terlihat kegiatan ekonomi masyarakat lebih banyak bergantung kepada usaha perikanan budidaya KJA yang dikembangkan dengan sistem polikultur. Menurut penelitian Amidarhana (2001) R/C ratio usaha budidaya ikan KJA dengan sistem polikultur tercatat sebesar 1,70, dibanding dengan sistem monokultur yang tercatat $\mathrm{R} / \mathrm{C}$ ratio sebesar 1,35 .

Dilihat dari total skor, Waduk Jatiluhur lebih tinggi dibandingkan dengan empat waduk lainnya. Hal ini disebabkan karena Waduk Jatiluhur merupakan waduk yang lebih dahulu dibangun dibandingkan dengan 4 waduk lainnya. Hal ini terbukti seperti yang terlihat pada Tabel 1, dimana dari lima lima sub sistem usaha tersebut empat diantaranya memiliki skor lebih tinggi dibanding empat waduk lainnya. Hanya pada Sub Sistem Layanan Pendukung saja yang nilainya berada di bawah Waduk Cirata. Dimana Waduk Cirata memperoleh skor 2,04 sedangkan Waduk Jatiluhur memperoleh skor ratarata 1,97. Kodisi ini juga ditengarai karena adanya perbedaan persepsi antar pemangku kepentingan, menurut Hidayat dkk (2016) tidak jelasnya aturan menjalankan usaha dari persepsi pemerintah dan pelaku usaha menimbulkan fluktuasi pada kondisi usaha perikanan tangkap di Waduk Cirata yang tercatat pada kurun tahun 2015 sebanyak 3.511,38 ton; dan tahun 2015, sebanyak 3,583,41 ton. Pilihan jenis ikan yang dibudidayakan juga berfluktuasi, karena perhitungan ekonomi. Nugroho (2011) mencatat jaminan harga terbaik untuk jenis ikan nila selain ikan mas pada KJA adalah dengan harga jual diatas $\mathrm{Rp}$ 11.000 per- kg, yaitu harga jual pada tahun 2011.

Lebih lanjut selisih skor hasil penelitian, terlihat pada kriteria Sarana

Transportasi, Fasilitas Komunikasi, dan Lembaga Keuangan. Disitu terlihat Waduk Jatiluhur memperoleh skor $(8,46)$, sedangkan Waduk Cirata memperoleh skor $(8,86)$. Lebih tingginya skor pada kriteria Sarana Transportasi, Fasilitas Komunikasi, dan Lembaga Keuangan di Waduk Cirata tersebut dapat disebabkan karena Waduk Cirata lebih banyak dijadikan sebagai destinasi liburan lantaran lokasinya yang lebih strategis dan mudah dijangkau, sehingga jumlah pengunjungnyapun lebih banyak.

$$
\text { Selanjutnya, jika }
$$
membandingkan skor antara Waduk 


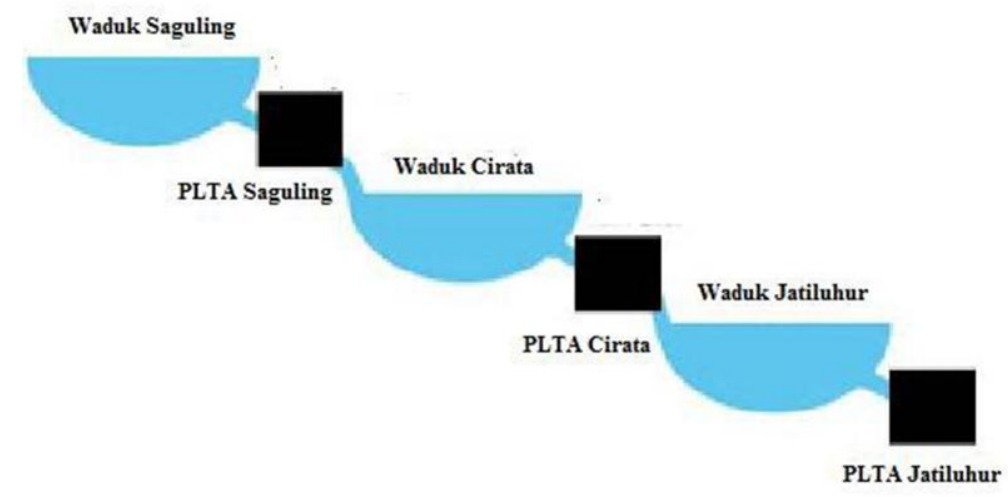

Gambar 1. Posisi letak tiga waduk kaskade (waduk yang berjenjang) dari arah hulu ke hilir Sungai Citarum

Jatiluhur dengan Waduk Saguling, maka Waduk Jatiluhur memiliki skor 0,10. lebih tinggi dibandingkan dengan Waduk Saguling, dimana Waduk Jatiluhur mendapatkan skor 10,89 sedangkan Waduk Saguling 10,86. Selisih itu terjadi karena dari skor lima sub sistem usaha tersebut, dua sub sistem usaha yang ada di Waduk Jatiluhur yaitu Sub Sistem Produksi dan Sub Sistem Pemasaran memperoleh skor lebih tinggi yaitu 1,71 dan 3,21 sedangkan di Waduk Saguling hanya memperoleh skor 1,47 dan 2,69. Hal ini dapat terjadi karena jika ditinjau dari letak lokasi waduk terhadap masuknya aliran Sungai Citarum (Gambar 1), ternyata Waduk Saguling lebih awal dilalui oleh aliran sungai tersebut. Dengan demikian tingkat sedimentasi di Waduk Saguling akan lebih besar dibandingkan dengan Waduk
Jatiluhur. Untuk kondisi ini, Radityo dkk (2013) mengatakan bahwa sebaiknya pemerintah menjalankan beberapa langkah kebijakan untuk menekan nilai ekonomi yang hilang dengan adanya pencemaran, kebijakan prioritas yang disarankan adalah: pengadaan instalasi waste filter. Hal ini diperkuat dengan kajian Hamzah dkk (2016) yang mengatakan bahwa kualitas air Waduk Jatiluhur khusunya Tarum-Barat sudah tercemar baik dilihat dari parameter fisik, kimia maupun biologi. Lebih lanjut dikatakan Hamzah dkk (2016), kondisi ini akibat langsung dari tata guna lahan atau konversi lahan di hulu yang tidak tepat, meningkatnya kegiatan industri, sampah, limbah domestik dan aktivitas manusia lainnya pada badan perairan waduk. Menurut Krismono dkk (2006), pada tahun 2006 saja sudah dianggap 
jumlah KJA telah melampaui daya dukung akibatnya terjadi penuruan kualitas air pada ketiga waduk berjenjang (Saguling, Cirata dan Jatiluhur) tersebut. Lebih lanjut Krismono dkk (2006) mengatakan bahwa pengelolaan "one river-one management" perlu dilakukan dengan menggalan peran aktif bersama antara para pemangku kepentingan, dalam hal ini: pengelola waduk, lembaga penelitian, akademisi, Pemerintah \& pemerintah daerah, Lembaga Swadaya Masyarakat, para penyuluh perikanan. pelaku usaha dan pelaku utama yang merupakan masyarakat setempat. Posisi letak tiga waduk yang berjenjang atau kaskade juga berperan menimbulkan peningkatan beban masukan di masing- masing waduk, khususnya pada waduk Saguling, Cirata dan Jatiluhur (Gambar 1.)

Kemudian, Jika melihat tampilan profil dan karakteristik waduk pada halaman sebelumnya yang dikutif dari sebuah website di internet yaitu Berikutnya, jika membandingkan antara Waduk Jatiluhur dengan Waduk Jatigede, maka berdasarkan Tabel 3 semua skor sub sistem usaha yang ada di Waduk Jatiluhur rata-rata berada lebih tinggi dibandingkan
(Anonimus ${ }^{-4), ~ 2017) ~ t e n t a n g ~ d a y a ~}$ tampung dan luas genangan waduk, maka Waduk Jatiluhur memiliki daya tampung dan luas genangan jauh lebih besar dibandingkan dengan Waduk Saguling. Waduk Jatiluhur mempunyai volume tampung air sebanyak 2,44 milyar $\mathrm{m} 3$ dengan luas genangan 8.300 ha, sedangkan Waduk Saguling hanya mempunyai volume tampung air sebanyak 875 juta m3 dengan luas genangan $2.271,7 \mathrm{~m} 2$. Atas dasar hal tersebut, maka bukan sesuatu yang tidak mungkin tingkat produksi yang terjadi di Waduk Jatiluhur jauh lebih tinggi dibandingkan dengan Waduk Saguling. Selanjutnya pada Sub Sistem Pemasaran skor yang diperoleh Waduk Jatiluhur jauh lebih tinggi dibandingkan dengan Waduk Saguling. Hal ini sudah pasti, karena ada kaitannya dengan Sub Sistem Produksi, dimana Sub Sistem Produksi di Waduk Jatiluhur seperti yang sudah dijelaskan sebelumnya memiliki skor lebih besar dibandingkan dengan Waduk Saguling.

dengan Waduk Jatigede. Dengan demikian jika total skor di Waduk Jatiluhur mencapai angka 10,96, di Waduk Jatigede hanya memperoleh 9,32. Hal ini menunjukkan dari total 19 kriteria yang tertuang dalam 5 sub 
sistem usaha, tidak ada satupun di Waduk Jatigede yang memperoleh skor lebih tinggi dibandingkan dengan Waduk Jatiluhur. Jika ditelaah pada Tabel 2, maka terlihat pada setiap nilai rata-rata yang ada pada setiap sub sistem usaha ternyata Waduk Jatiluhur lebih unggul dibandingkan Waduk Jatigede. Misalnya saja pada Sub Sistem Produksi (Waduk Jatiluhur $=$ 1,71 dan Waduk Jatigede =1,53), Sub Sistem Pasca Produksi (Waduk Jatiluhur

$=2,18$ dan Waduk Jatigede $=1,63)$, Sub Sistem Pemasaran (Waduk Jatiluhur $=3,21$ dan Waduk Jatigede $=2,43$ ), Sub Sistem Layanan Pendukung (Waduk Jatiluhur $=1,97$ dan Waduk Jatigede $=1,84$ ), sedangkan pada Sub Sistem Sarana Produksi antara kedua waduk ini memiliki skor yang sama yaitu sama- sama memperoleh skor 1,89. Hal ini mengindikasikan bahwa mulai dari sarana produksi hingga layanan pendukung perikanan di Waduk Jatiluhur jauh lebih tersedia dibandingkan dengan Waduk Jatigede. Semua ini dikarenakan Waduk Jatigede termasuk waduk yang usianya masih tergolong muda jika dibandingkan dengan Waduk Jatiluhur. Dengan kondisi seperti di atas, maka dapat diartikan aktivitas kegiatan masyarakat perikanan di Waduk Jatiluhur jauh lebih hidup dibandingkan dengan aktivitas di Waduk Jatigede.

Waduk terakhir yang perlu dibandingkan dengan Waduk Jatiluhur adalah Waduk Darma. Jika melihat Tabel 2, maka antara Waduk Jatiluhur dengan Waduk Darma terjadi selisih skor yang cukup signifikan. Waduk Jatiluhur memperoleh skor 10,96 sedangkan Waduk Darma 8,92. Selisih yang cukup signifikan ini dikarenakan adanya perbedaan usia waduk. Jika Waduk Jatiluhur merupakan waduk yang pertama kali didirikan yaitu pada tahun 1957, sedangkan Waduk Darma didirikan pada tahun 1965. Jika ditinjau dari Tabel 2, dari 5 sub sistem usaha yang menjadi bahan penilaian, empat (4) sub sistem diantaranya memiliki skor yang tinggi dan dimiliki oleh Waduk Jatiluhur. Empat (4) sub sistem dimaksud adalah: a). Sub Sistem Sarana Produksi (Waduk Jatiluhur $=1,89$ dan Waduk Darma = 1,82), b). Sub Sistem Produksi (Waduk Jatiluhur $=1,71$ dan Waduk Darma $=1,25)$, c). Sub Sistem Pasca Produksi $($ Waduk Jatiluhur $=2,18$ 
dan Waduk Darma $=1,50)$, d). Sub Sistem Pemasaran (Waduk Jatiluhur $=$ 3,21 dan 2,25). Perbedaan skor tersebut juga dapat disebabkan oleh jarak lokasi waduk dengan Jakarta sebagai pusat Ibu Kota. Menurut salah satu situs internet $\left(\right.$ Sanonimu $u^{-4)}$ 2017) Jarak Kabupaten Purwakarta dengan Jakarta sejauh 113 km, sedangkan Jarak Kabupaten Kuningan dengan Jakarta sejauh 293 $\mathrm{km}$. Selisih jarak itulah yang menjadi penyebab skor sub sistem usaha yang ada di Waduk Jatiluhur lebih tinggi dibandingkan dengan Waduk Darma. Dengan demikian, ini berarti bahwa aktivitas perikanan masyarakat di Waduk Jatiluhur jauh lebih hidup dibandingkan dengan aktivitas perikanan masyarakat di Waduk Darma.

\section{SIMPULAN DAN SARAN}

\section{Simpulan.}

Berdasarkan hasil penelitian dan pembahasan maka diperoleh simpulan sebagai berikut :

1. Dari lima waduk di Jawa Barat, Waduk Jatiluhur termasuk peringkat pertama pada kategori masyarakat yang paling aktif dalam kegiatan ekonomi di bidang perikanan. Hal ini ditunjukkan dengan total skor $(10,96)$ yang diperoleh dari skor rata-rata 5 sub sistem usaha. Disusul oleh Waduk Saguling (10,86), Waduk Cirata $(9,24)$, Waduk Jatiluhur $(9,32)$, dan Waduk Darma $(8,92)$.

2. Dilihat dari skor pada setiap subsistem usaha, di masyarakat perikanan pada Waduk Saguling cenderung terlihat lebih tinggi aktivitasnya dibandingkan pada masyarakat di Waduk Jatiluhur. Tetapi jika dilihat dari total skor dari lima subsistem usaha, masyarakat perikanan di Waduk Jatiluhur cenderung lebih tinggi aktivitasnya jika dibandingkan dengan Waduk Saguling dan tiga waduk lainnya.

3. Data perolehan skor paling tinggi dari setiap sub sistem usaha adalah sebagai berikut

a. Subsistem Sarana Produksi, berada di Waduk Saguling dengan skor $(2,32)$ 
b. Subsistem Produksi,

berada pada sekitar

Waduk Cirata dengan

skor $(1,72)$ Subsistem

Pasca Produksi,

berada di Waduk

Saguling dengan skor

c. Subsistem pada Pemasaran, berada di Waduk Saguling dengan skor $(2,39)$

d. Subsistem kegiatan

Layanan Pendukung, yang berada di Waduk Darma dengan skor $(2,10)$

\section{Saran.}

Berdasarkan kesimpulan di atas, maka disarankan agar masyarakat di sekitar waduk tetap memperahtian kegiatan perikanan yang berwawasan lingkungan tetap menjaga keberlanjutan usaha perikanan yang lestari.

\section{PERSANTUNAN}

Ucapan terimakasih disampaikan kepada Ketua Jurusan Penyuluhan Perikanan, Sekolah Tinggi Perikanan, yang telah memfasilitasi pendanaan penelitian ini, kepada para penyuluhperikanan di lima lokasi waduk yang yang telah memfasilitasi bantuan peralatan dan data, selama penelitian.

\section{DAFTAR PUSTAKA}

Amidarhana A. 2001. Analisis produktivitas usaha budidaya ikan dalam karamba jaring apung di Waduk Jatiluhur, Kabupaten Purwakarta, Provinsi Jawa Barat. Skripsi. Program Studi Sosial Ekonomi Perikanan, Fakultas Perikanan dan Ilmu Kelautan , Institut Pertanian Bogor, 48 hal.

Andrijanto dan WS Pamungkas. 2011. Sejarah bendungan Jatiluhur. https://jatiluhur.dam.wordpress. com .2011. Diakses, 3 Agustus 2017 pukul $20.30 \mathrm{WIB}$

Anonimus ${ }^{1)}$. 2017. Sekilas tentang ben dungan Jatiluhur. https://jati luhurdam.word press.com. 2017. Diakses, 4 Agustus 2017 pukul 01.35 WIB

Anonimus ${ }^{2)}$. 2017. Perhitungan kapa sitas tampungan waduk. https:/ /www.slideshare.net.2017.

Diakses 3 Agustus 2017 pukul 20.45 WIB

Anonimus ${ }^{3)}$. 2017. Waduk Saguling. https://id.wikipedia.org.2017.

Diakses, 2 Agustus 2017 pukul 19.20 WIB

Anonimus ${ }^{4)}$. Waduk Jatigede. https://id. $\quad$ wikipedia.org. 2017..Diakses, 4 Agustus 2017 pukul. 01.55 WIB

Hamzah, M. Syamsul Maarif, Marimin dan Etty Riani. 2016. Status mutu air Waduk jatiluhur dan ancaman terhadap proses 
bisnis vital. Jurnal Sumber Daya Air Vol 12 (1) Mei 2016.

Hidayat A, DM Marits, P Gandhi. 2016. Analisis kelembagaan pengelolaan waduk Cirata. Jurnal Risalah Kebijakan Pertanian dan Lingkungan, Vol. 3 (2) tahun 2016.

http://www.pikiranrakyat.com.2017.TitikTerdalam Waduk-DarmaMaksimum Hanya Mencapai 17 Meter. Diakses, 4 Agustus 2017 Pkl. 20.30 WIB

Iman Sungkawa. 2016 Waduk Darma Miliki Multi Fungsi. https:// identitasbangsa. wordpress. com. 2017.. Diakses, 3 Agustus 2017 pukul 20.45.

Kartamihardja ES. 1998. Pengembangan dan pengelolaan budidaya ikan dalam keramba jaring apung ramah lingkungan di perairan waduk dan danau serbaguna, Prosiding Simposium Perikanan Indonesia II: 174-182. Ujung Pandang.

Krismono, Astuti dan L Pujiyani. 2006. Pengelolaan waduk kaskade (Saguling, Cirata, Jatiluhur) untuk budidaya ikan dalam karamba jaring apung (KJA). Prosiding Seminar Nasional Ikan IV: 225229. Jatiluhur, 29-30 Agustus 2006.

Nugroho E. 2011. Kajian lapang bu didaya keramba jaring apung ikan nila "Mandiri" di waduk Cirata dan Jatiluhur. Pusat riset perikanan, Badan riset dan sumber daya manusia kelautan dan perikanan. Media Akuakultur Vol. 6 (1) th 2011.
Radityo R, Kusumastanto T, Nababan BO. 2013. Dampak ekonomi pencemaran air terhadap perikanan budidaya sistem keramba jaring apung (KJA) di Waduk Cirata, Kabupaten Bandung Barat. IPB Sientific Repository. Copyright@ Central library of Bogor Agricultural University.

Sukimin S. 1999. Pengelolaan dan pemanfaatan peraiaran waduk Ir. H. Djuanda untuk perikanan yang berwawasan lingkungan. Pro siding Semiloka Nasional Pengelolaan dan Pemanfaatan Waduk, hal XII-1 - XII-9. Bogor

Tjokrokusumo SW. 2000. Pengelolaan kualitas dan kuantitas air sungai untuk kelestarian Waduk Saguling, Cirata dan Jatiluhur. Prosiding Pengelolaan dan Pemantauan Danau dan Waduk. Jurusan Perikanan, Fakultas Pertanian Universitas Padjadjaran, Bandung. 